\title{
Removal of Iron from Hard Zinc for Production of Refined Zinc
}

\author{
M.A. Barakat* \\ Central Metallurgical R\& D Institute, P.O. Box 87 Helwan 11421, Cairo, Egypt
}

\begin{abstract}
Refining of hard zinc through removal of iron has been investigated in this study. Zinc powder, aluminum turnings, and mixture of both of them have been tested and evaluated as refining agents. The hard zinc samples with the additives were charged in an electric muffle furnace at a temperature range from 600 to $900^{\circ} \mathrm{C}$. Iron oxide and its intermetallic compounds of $\mathrm{Fe}$ with $\mathrm{Zn}$ have been formed as a slag of refining in the sink of the crucible, while that of the intermetallic compounds of $\mathrm{Fe}$ with $\mathrm{Al}$ have been floated on the melt bath surface and skimmed. Several characterization and analytical tools, such as X-Ray Diffraction (XRD), Scanning Electron Microscopy (SEM), Energy Dispersive X-ray Analysis (EDAX), and Atomic Absorption Spectroscopy (AAS) were used to investigate the phases, surface microstructure, and composition of the hard and refined zinc samples. Different parameters affecting the refining process such as amount of the refining agents, refining duration and temperature have been studied. Results obtained revealed that removal of iron from hard zinc was achieved with different refining agents in the order; aluminum turnings > zinc dust> $\mathrm{Al} / \mathrm{Zn}$ mixture. A refined zinc was obtained by adding $0.4 \mathrm{wt} \% \mathrm{Al}$ at $700{ }^{\circ} \mathrm{C}$ after $2 \mathrm{~h}$ of refining with lowering the iron concentration from $3.2 \%$ in the hard zinc to $0.5 \%$ in the refined product.
\end{abstract}

Key Words: Hard zinc, iron removal, refining, refined zinc, aluminum turnings.

\section{INTRODUCTION}

In the factories, which are working in the field of steel industry, hot dip galvanizing process consists of steel sheets and pipes being immersed in the molten zinc for sufficient time for corrosion protection. During the process of hot-dip zinc coating, the bath becomes segregated due to cooling. This results in accumulation of crystallite of intermetallic compounds of $\mathrm{Zn}_{\mathrm{n}} \mathrm{Fe}_{\mathrm{m}}$ type as precipitate which settle down as being heavier [1]. The mixed alloy of liquid zinc with intermetallic phase crystals containing 3-6 wt $\% \mathrm{Fe}$ is called "hard zinc". Although this material is rich in zinc $(\sim 94-97 \%)$, it can not be reused in the galvanization processes since the minimum grade of the metallic zinc used in galvanization should be around $99 \%$. Most of the previous studies related to zinc refining have been patented. As the primary South African metallurgical technology provider, Mintek became involved in the evaluation of a pyrometallurgical process for the recovery of zinc from the Gamsberg deposit. This includes the patented Enviroplas ${ }^{\circledR}$ process for the treatment of zinc bearing waste materials [2-5]. New Jersey process is a pyrometallurgical technology available for the refining of prime western grade (PWG) zinc to special high grade (SHG) zinc. The modelling of the process included the use of both a packed distillation column and vacuum based distillation [6,7]. A new technology for the pyrometallurgical refining of zinc has been developed (the so-called Zincref technology) in South Africa. The process consists of a DC arc furnace to evaporate the zinc, connected to a refractory lined packed distillation column for refining the zinc, and finally a surface condenser for

*Address correspondence to this author at the Central Metallurgical R\& D Institute, P.O. Box 87 Helwan 11421, Cairo, Egypt;

E-mail: mabarakat@gmail.com condensing the distilled zinc [8]. Devilee, et al. [9] studied the removal of iron from a zinc chloride melt. An investigation into the cementation of iron chloride from a zincchloride melt has been carried out with zinc powder at $400{ }^{\circ} \mathrm{C}$. The objective of this study is the removal of iron impurities for hard zinc refining. The economical target is based on re-using such materials in the steel galvanization process. This is also enhanced with the target of decreasing the environmental pollution as these materials contain toxic species.

\section{EXPERIMENTAL}

\subsection{Materials and Chemicals}

A sample of hard zinc weighing $10 \mathrm{~kg}$ was provided by Helwan Co. for Machines and Tools, Helwan, Egypt. The sample was cut by an electrical saw to small samples of about $100 \mathrm{~g}$ each. Pure zinc powder and aluminum turnings (type M.S.O. Laboratory Chemicals) were used as the refining agents.

\subsection{Refining Processes of Hard Zinc}

The experiments were carried out on a laboratory scale of $100 \mathrm{~g}$ of each sample. Thermal experiments were carried out for the hard zinc samples in silicon-carbide crucibles (type Salimendar). The samples with the additives ( $\mathrm{Zn}$ powder, aluminum turnings, and mixture of both of them)were placed in an electric muffle furnace (Model Naberthern, Germany). The temperature was gradually elevated up to the required degree $\left(600-900^{\circ} \mathrm{C}\right)$, in about 30 minute, and maintained at the required maximum temperature level during the refining time. Iron oxide and its intermetallic compounds of Fe with $\mathrm{Zn}$ have been formed as a slag of refining in the sink of the crucible, while that of the intermetallic compounds of $\mathrm{Fe}$ with $\mathrm{Al}$ have been floated on the melt bath surface and skimmed. The molten metal was 
casted in alumina molds after skimming of the formed slag. The produced zinc ingots were weighed and analyzed.

\subsection{Characterization and Assay Methods}

Samples of the produced refined zinc and slag of refining were subjected to X-Ray analysis with X-Ray diffractometer model BRUKER, D8 ADVANCE with Ni-filter, Cu-radiation $\left(=1.542 \mathrm{~A}^{\circ}\right)$ at $40 \mathrm{kV}, 30 \mathrm{MA}$ and scanning speed $0.02 \% \mathrm{sec}$. Metal concentrations in the hard, intermediate, and refined samples were assayed by using atomic absorption spectrophotometer, model Perkin Elmer A Analyst 200 with air-acetylene flame. Scanning Electron Microscope (SEM) JOEL model JSM-5410 and Energy Dispersive X-Ray Analysis (EDAX) model Pentafet Link, OXFORD, were used to investigate the surface microstructure, and composition of the hard, intermediate, and refined zinc samples.

\section{RESULTS AND DISCUSSION}

\subsection{Refining Processes}

Table 1 shows the chemical composition of the used hard zinc sample. It is seen that the sample contained about $3.2 \mathrm{wt}$ $\%$ iron impurities. On the other hand, the limit of iron concentration in the refined zinc material should be less than $1 \mathrm{wt} \%$ (according to the standard specifications given by the Company).

Table 1. Chemical Analysis of the Hard Zinc Sample (AAS Analysis)

\begin{tabular}{|c|c|}
\hline Metal & wt \% \\
\hline \hline $\mathrm{Zn}$ & 96.8 \\
\hline $\mathrm{Fe}$ & 3.2 \\
\hline
\end{tabular}

A pyrometallurgical treatment for the refining of hard zinc samples was performed with the addition of different refining agents such as; zinc powder, aluminum turnings, and their mixture as shown in Figs. (1-3). Effect of addition of zinc powder on the removal of iron from hard zinc, at 650 ${ }^{\circ} \mathrm{C}$ for $2 \mathrm{~h}$, is shown in Fig. (1). From the figure, it can be seen that, the increasing addition of zinc powder resulted in gradual decrease in the iron content of hard zinc from $3.2 \%$ without zinc addition to $0.98 \%$ after the addition of $10 \%$ zinc powder. A further increase in the zinc addition amount almost had no effect on the removal of iron. The effect of zinc powder addition on hard zinc refining can be explained as follows; as mentioned before, iron is present within hard zinc as intermetallic compounds of $\mathrm{Zn}_{\mathrm{n}} \mathrm{Fe}_{\mathrm{m}}$ type. On addition of zinc powder to the hard zinc melt, a new intermetallic $\mathrm{Zn} / \mathrm{Fe}$ compound can be formed in the slag of refining (in the sink of the crucible as it is heavier than $\mathrm{Zn}$ melt). On the other hand, a part of the $\mathrm{Zn}$ powder may be oxidized to $\mathrm{ZnO}$ and a metallothermic reduction of $\mathrm{ZnO}$ with liquid iron (in the intermetallic phase) can be achieved according to the following reactions:

$\mathrm{ZnO}(\mathrm{s})+\mathrm{Fe}(\mathrm{l})=\mathrm{Zn}(\mathrm{l})+\mathrm{FeO}(\mathrm{s})$

$\mathrm{FeO}+{ }^{1} / 2 \mathrm{O}_{2}=\mathrm{Fe}_{2} \mathrm{O}_{3}$
However, a large amount of the formed $\mathrm{ZnO}$ can not be reduced through this reaction. The kinetics of the reduction of $\mathrm{ZnO}$ by iron is known to be chemically controlled at the temperature range of $800-1150{ }^{\circ} \mathrm{C}$ [10].

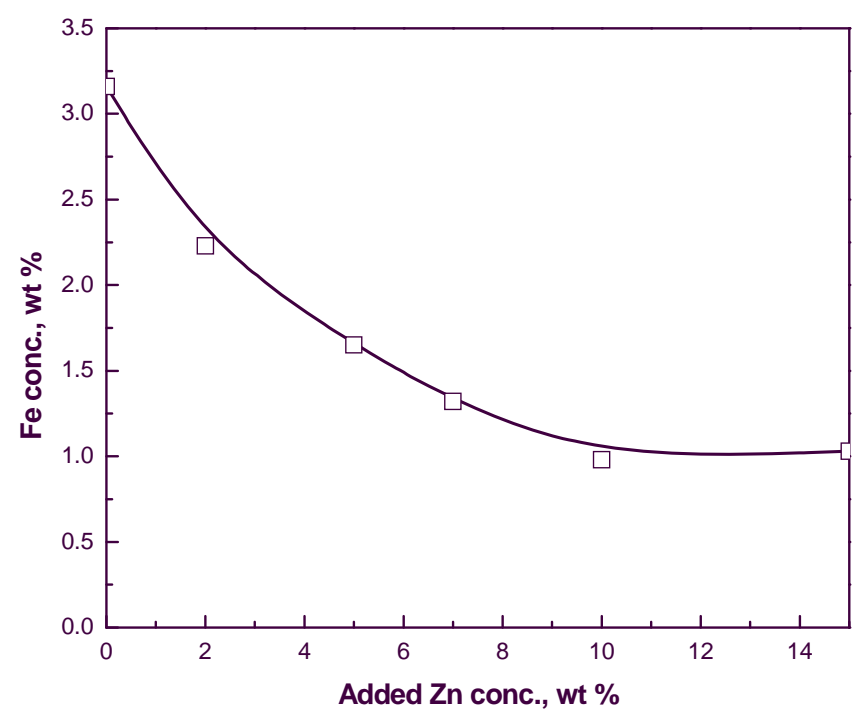

Fig. (1). Effect of $\mathrm{Zn}$ addition on hard zinc refining (iron removal) (at $650{ }^{\circ} \mathrm{C}$ for $2 \mathrm{~h}$ ).

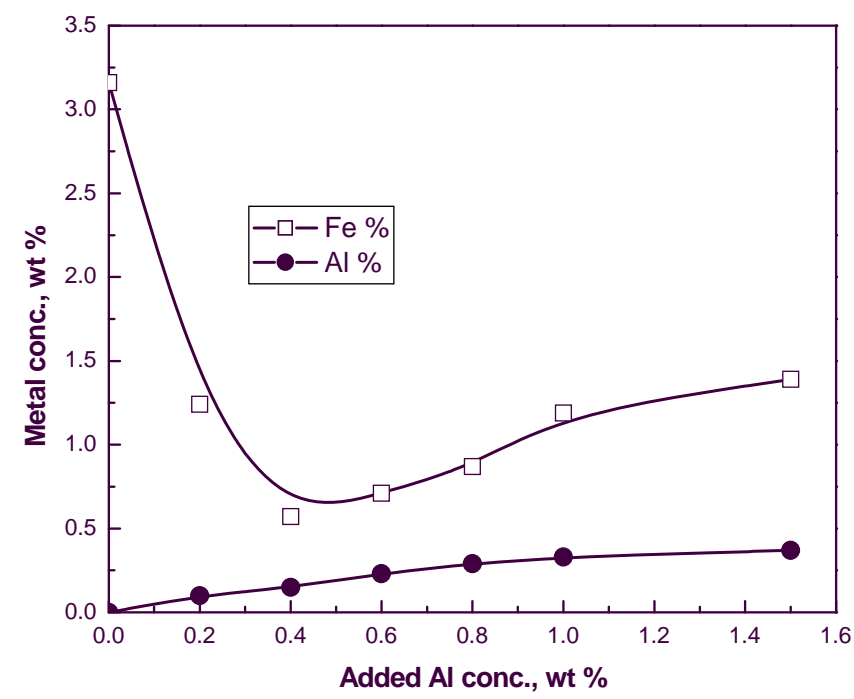

Fig. (2). Effect of Al addition on hard zinc refining. (at 650 ${ }^{\circ} \mathrm{C}$ for $2 \mathrm{~h}$ ).

Aluminum turnings as another refining agent was also investigated, the effect of different amounts of additions of aluminum on the removal of iron from hard zinc, at $650{ }^{\circ} \mathrm{C}$ for $2 \mathrm{~h}$, is shown in Fig. (2). It can be seen from Fig. (2) that an inversed parabolic shape was found for the Fe removal behavior from hard $\mathrm{Zn}$ due to $\mathrm{Al}$ addition. A small amount of addition of $\mathrm{Al}$ is required to decrease $\mathrm{Fe}$ concentration in the refined $\mathrm{Zn}$ to a low level. The minimum $\mathrm{Fe}$ concentration value of $0.57 \mathrm{wt} \%$ was obtained with $\mathrm{Al}$ addition of $0.4 \mathrm{wt} \%$ (at $650{ }^{\circ} \mathrm{C}$ for $2 \mathrm{~h}$ ). A further increase in the amount of $\mathrm{Al}$ addition resulted in a gradual increase in the Fe concentration. Iron content of $1.39 \mathrm{wt} \%$ was obtained in refined $\mathrm{Zn}$ 
sample after addition of $1.5 \mathrm{wt} \%$ of Al. On the other hand, a little content of $\mathrm{Al}$ was observed in the refined $\mathrm{Zn}$, which increased with the increasing $\mathrm{Al}$ addition. Values of 0.15 and $0.37 \mathrm{wt} \%$ of $\mathrm{Al}$ concentration in the refined $\mathrm{Zn}$ were obtained after the addition of 0.4 and $1.5 \mathrm{wt} \%$ of $\mathrm{Al}$, respectively. The effect of $\mathrm{Al}$ addition on the Fe removal from hard $\mathrm{Zn}$, during the refining process, can be explained as follows; in hard $\mathrm{Zn}$, several $\mathrm{Zn}-\mathrm{Fe}$ intermetallics are formed when steel is dipped in molten $\mathrm{Zn}$. The tendency of $\mathrm{Al}$ to form intermetallic phases with $\mathrm{Fe}$ (e.g.: $\mathrm{FeAl}_{2}, \mathrm{FeAl}_{3}, \mathrm{Fe}_{2} \mathrm{Al}_{3}$ ) is higher than that of $\mathrm{Zn}$ with $\mathrm{Fe}$ [11]. Fig. (3) shows the effect of $\mathrm{Zn} / \mathrm{Al}$ mixture addition on the removal of iron from hard zinc, at $650{ }^{\circ} \mathrm{C}$ for $2 \mathrm{~h}$ for different amounts of additions of $\mathrm{Zn}$ powder in presence of a fixed amount of Al. It was obvious from the figure that the addition of $\mathrm{Zn}$ in the presence of $0.4 \mathrm{wt} \% \mathrm{Al}$ had an inverse effect on the removal of Fe from hard $\mathrm{Zn}$. This may be due to the fact that portion of the added $\mathrm{Zn}$ particles were oxidized, on the surface of $\mathrm{Zn}$ melt. The oxidized species could be worked as barriers which hindered or lowered the probability of the formation of intermetallic phases between $\mathrm{Al}$ and $\mathrm{Fe}$ in the $\mathrm{Zn}$ melt.

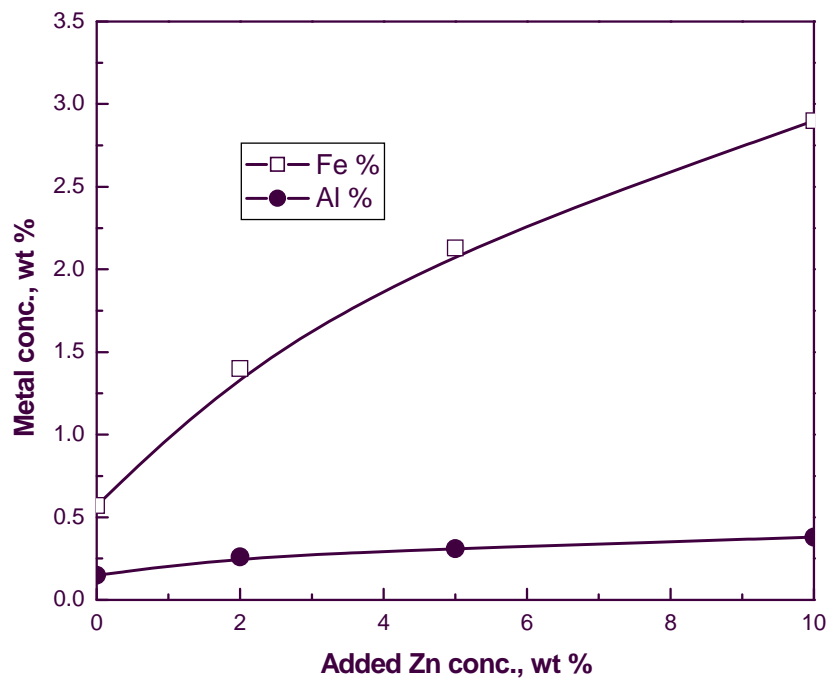

Fig. (3). Effect of addition of $\mathrm{Zn}$ and $\mathrm{Al}$ mixture on hard zinc refining (in the presence of $0.4 \mathrm{wt} \% \mathrm{Al}$ at $650{ }^{\circ} \mathrm{C}$ for $2 \mathrm{~h}$ ).

The effect of duration on the removal of Fe from hard $\mathrm{Zn}$, by adding $0.4 \mathrm{wt} \%$ of $\mathrm{Al}$ and $10 \mathrm{wt} \%$ of $\mathrm{Zn}$ independently, at $650{ }^{\circ} \mathrm{C}$ is illustrated in Fig. (4). It can be seen that the Fe concentration in the refined $\mathrm{Zn}$ decreased as duration increased up to $2 \mathrm{~h}$. A further increase in duration had no positive effect on the $\mathrm{Zn}$ refining. The Fe concentration values in the refined samples were $0.98 \%$ with adding $\mathrm{Zn}$ powder and $0.57 \%$ with adding Al. The effect of temperature on the hard $\mathrm{Zn}$ refining after $2 \mathrm{~h}$, by adding $0.4 \mathrm{wt} \%$ of $\mathrm{Al}$ and $10 \mathrm{wt} \%$ of $\mathrm{Zn}$ independently, is shown in Fig. (5). A parabolic shaped curve was obtained and the $\mathrm{Fe}$ concentration in the refined $\mathrm{Zn}$ decreased to minimum values of $0.98 \%$ at $650{ }^{\circ} \mathrm{C}$ with adding $\mathrm{Zn}$ powder, and $0.5 \%$ at 700 ${ }^{\circ} \mathrm{C}$ with adding $\mathrm{Al}$, respectively. A further increase in the temperature resulted in a gradual increase in the Fe concentration in the two series. The temperature effect can be explained as follows; a complete melting for the hard $\mathrm{Zn}$ sample was observed at $600{ }^{\circ} \mathrm{C}$. The temperature value of $650{ }^{\circ} \mathrm{C}$ was the optimum one with $\mathrm{Zn}$ series (melting point of $\mathrm{Zn}$ is $420^{\circ} \mathrm{C}$ ). On the other hand, the optimum temperature for $\mathrm{Zn}$ refining with $\mathrm{Al}$ series was $700{ }^{\circ} \mathrm{C}$. This was due to the fact that this temperature was just above the melting point of $\mathrm{Al}\left(660^{\circ} \mathrm{C}\right)$, Further increases in temperature (in both series) resulted in a partial oxidation of $\mathrm{Zn}$ in the melt and so its concentration decreased in the refined $\mathrm{Zn}$ and consequently the $\mathrm{Fe} \%$ increased.

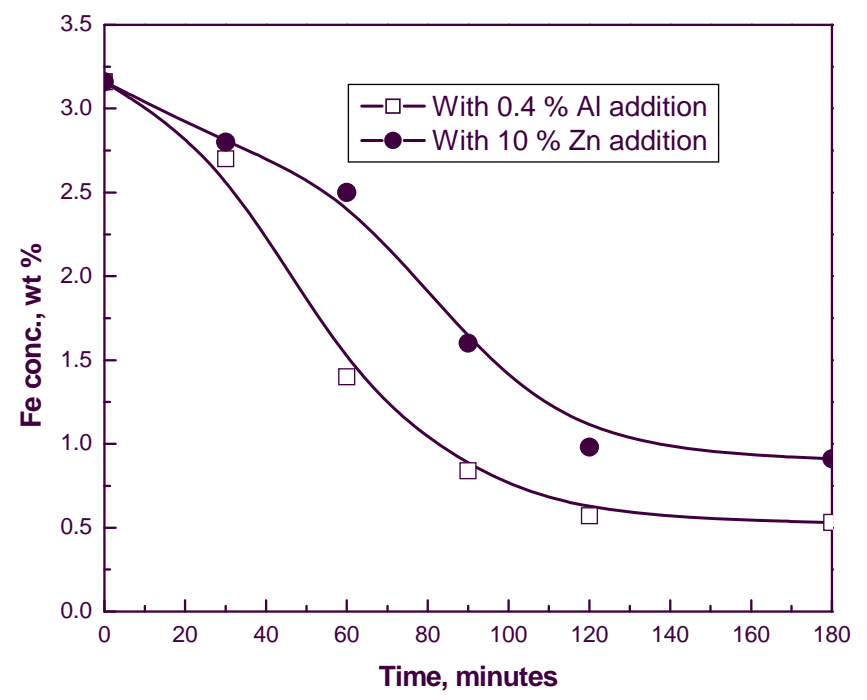

Fig. (4). Effect of time on hard zinc refining (with $0.4 \mathrm{wt} \%$ of $\mathrm{Al}$ or $10 \mathrm{wt} \%$ of $\mathrm{Zn}$ independently at $650{ }^{\circ} \mathrm{C}$ ).

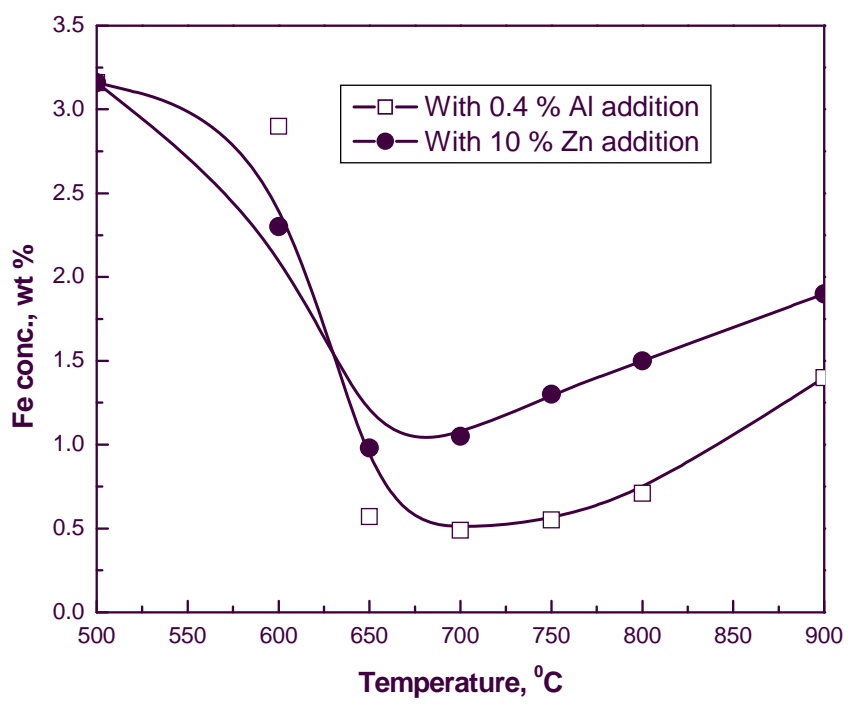

Fig. (5). Effect of temperature on hard zinc refining (with 0.4 wt $\%$ of $\mathrm{Al}$ or $10 \mathrm{wt} \%$ of $\mathrm{Zn}$ independently for $2 \mathrm{~h}$ ).

\subsection{Characterization Processes}

The XRD patterns for phase identification of both of the refined $\mathrm{Zn}$ sample and the slag of refining are shown in Figs. (6 and 7), respectively. The XRD pattern of the refined $\mathrm{Zn}$ sample (with $0.4 \mathrm{wt} \% \mathrm{Al}$ ) in Fig. (6) showed only the $\mathrm{Zn}$ phase, which preliminary confirms the refining process. Fig. (7) showed the XRD patterns for the slag of refining by using three series; 1) $10 \% \mathrm{Zn}$, 2) $0.4 \% \mathrm{Al}$, and 3) mixture 
of $10 \% \mathrm{Zn}$ with $0.4 \% \mathrm{Al}$. It can be seen that phases of zinc oxide $(\mathrm{ZnO})$, hematite $\left(\mathrm{Fe}_{2} \mathrm{O}_{3}\right)$, and quartz, low $\mathrm{SiO}_{2}$ (originating from the $\mathrm{Si}-\mathrm{C}$ crucible material) were present in the all series. Phase of iron-zinc $\left(\mathrm{Fe}_{3} \mathrm{Zn}_{10}\right)$ was detected in series 1 (due to $\mathrm{Zn}$ addition) which confirmed the formation of such intermetallic compound (in the sink of the crucible) due to the refining process. On the other hand, phases of aluminum oxide $\left(\mathrm{Al}_{2} \mathrm{O}_{3}\right)$ and aluminum iron, $\left(\mathrm{FeAl}_{2}\right)$ were present in series 2 and 3 (due to $\mathrm{Al}$ and $\mathrm{Zn} / \mathrm{Al}$ mixture additions). These XRD patterns confirmed the formation of $\mathrm{FeAl}_{2}$ intermetallic phase which floated on the bath surface due to its lower density compared to the remaining phases in $\mathrm{Zn}$ alloy bath. These findings were also identical to those of Dionne [1].

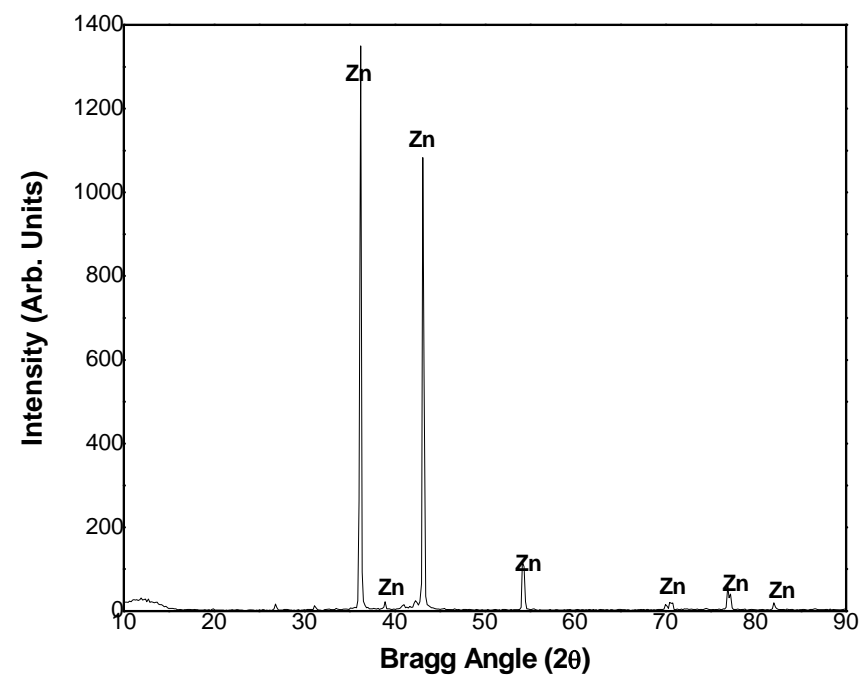

Fig. (6). XRD pattern for the refined zinc ingot after refining with $\mathrm{Al}$ (with $0.4 \mathrm{wt} \%$ of $\mathrm{Al}$ for $2 \mathrm{~h}$ at $700{ }^{\circ} \mathrm{C}$ ).

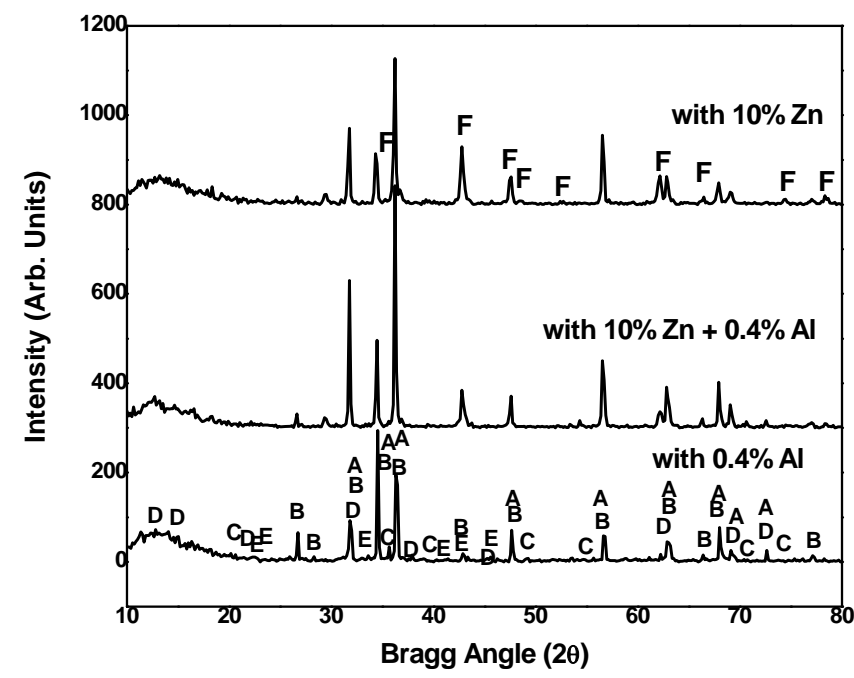

Fig. (7). XRD pattern for the slag produced from hard zinc refining with $\mathrm{Al}, \mathrm{Zn}$, and $\mathrm{Al} / \mathrm{Zn}$ mixture (at the optimum refining conditions of each reagent).
A: Zinc oxide, $\mathrm{ZnO}$
B: Quartz, low $\mathrm{SiO}_{2}$
C: Hematite, $\mathrm{Fe}_{2} \mathrm{O}_{3}$
D: Aluminum oxide, $\mathrm{Al}_{2} \mathrm{O}_{3}$
E: Aluminum iron, $\mathrm{FeAl}_{2}$

EDAX characterization was performed to confirm the samples surface composition. Fig. (8) and Table 2 demonstrate the EDAX patterns and data for both of the hard and refined zinc samples (with $0.4 \% \mathrm{Al}$ ). It is obvious that the intensity of the Fe peak in the hard Zn (Fig. 8-a) was decreased with the appearance of $\mathrm{Al}$ peak in the refined sample (Fig. 8-b). Table 2 also shows the lowering of the Fe concentration from 3.2 to $0.5 \mathrm{wt} \%$, due to the refining process.

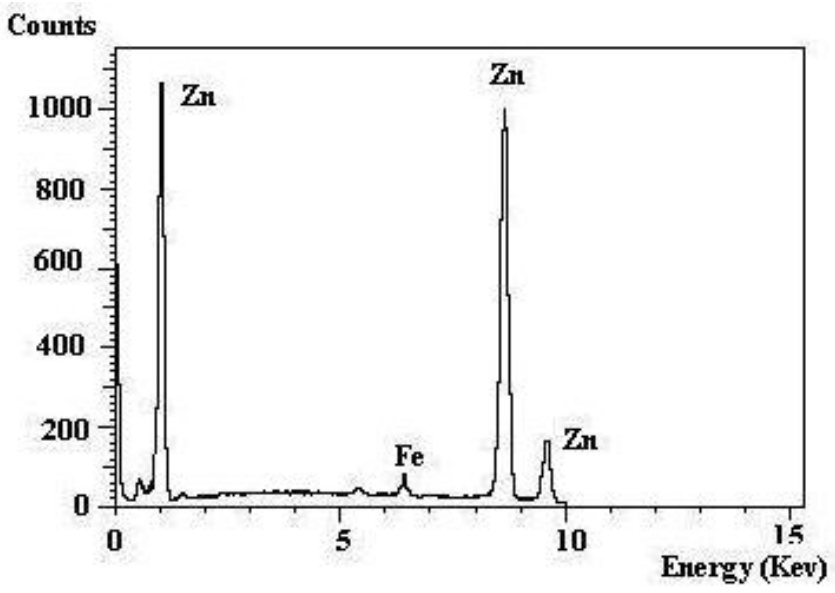

a) Hard zinc sample

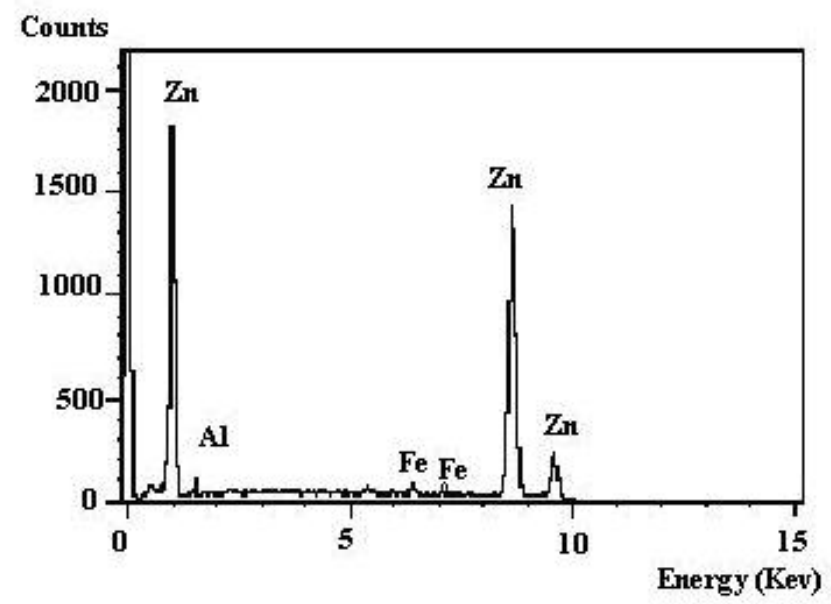

b) Refined zinc sample

(with $0.4 \% \mathrm{Al}$ at $700{ }^{\circ} \mathrm{C}$ for $2 \mathrm{~h}$ )

Fig. (8). EDAX patterns for both of hard and refined zinc samples a) Hard zinc sample b) Refined zinc sample (with $0.4 \%$ $\mathrm{Al}$ at $700{ }^{\circ} \mathrm{C}$ for $2 \mathrm{~h}$ ).

Table 2. EDAX Analysis for the Hard Zinc and Refined Zinc Samples

\begin{tabular}{|c|c|c|}
\hline Metal, wt \% & Hard Zinc & Refined Zinc* \\
\hline \hline $\mathrm{Zn}$ & 96.8 & 99.3 \\
\hline $\mathrm{Fe}$ & 3.2 & 0.5 \\
\hline $\mathrm{Al}$ & 0 & 0.2 \\
\hline
\end{tabular}

* with $0.4 \mathrm{wt} \% \mathrm{Al}$ at $700{ }^{\circ} \mathrm{C}$ after $2 \mathrm{~h}$ of refining. 
Microstructures of both of the hard and refined zinc samples (with $0.4 \% \mathrm{Al}$ ) are illustrated as SEM pictures in Fig. (9). The etchant solution was composed of $\mathrm{CrO}_{3} / \mathrm{Na}_{2} \mathrm{SO}_{4}$ mixture as described in the ASM Handbook [12]. The interaction between the base $\mathrm{Zn}$ material and impurities such as $\mathrm{Fe}$ and $\mathrm{Al}$ resulted in interesting microstructure profiles. Iron appeared in the microstructure as an intermetallic compound, the particle size was controlled by the amount of Fe present. Fig. (9-a) showed that the Fe/Zn particles were elongated in the rolling direction (white gray). The microstructure of the refined sample (Fig. 9-b) showed the size reduction of the intermetallic Fe/Zn particles. This was due to the presence of the Al which acted as a grain refiner in the cast $\mathrm{Zn}$ [12].

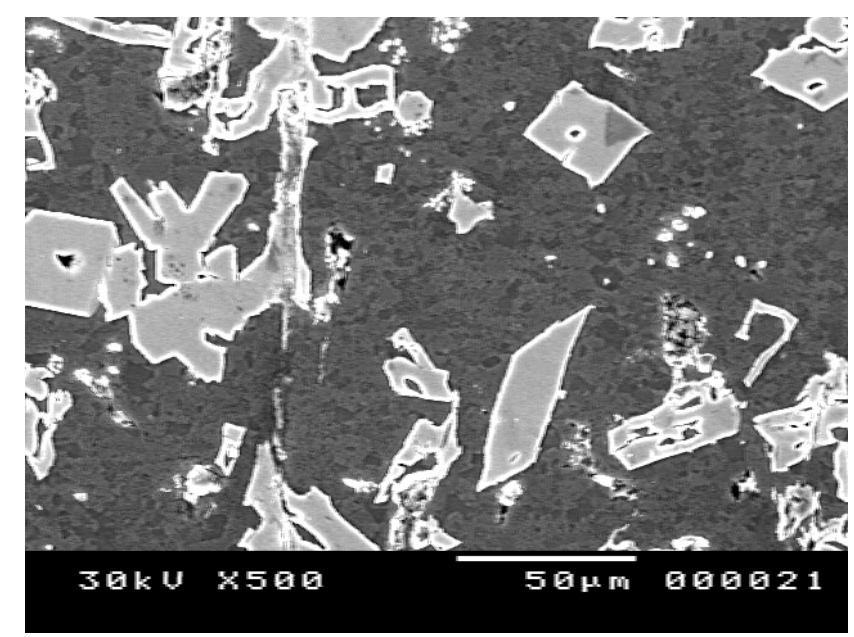

a) Hard zinc sample

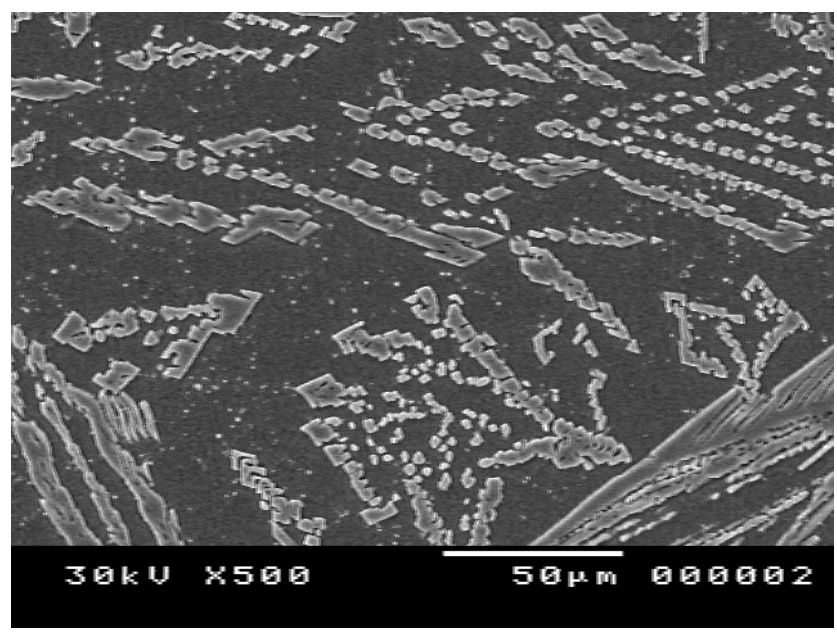

b) Refined zinc sample

(with $0.4 \% \mathrm{Al}$ at $700{ }^{\circ} \mathrm{C}$ for $2 \mathrm{~h}$ )

Fig. (9). SEM pictures for both of hard and refined zinc samples (As polished after etching in chromate solution, 500X).

\section{CONCLUSIONS}

Hard zinc refining through removal of iron was successfully achieved by using different refining agents in the order; aluminum turnings $>$ zinc powder $>\mathrm{Al} / \mathrm{Zn}$ mixture. Iron is present within hard zinc as intermetallic compounds in the form of $\mathrm{Zn}_{\mathrm{n}} \mathrm{Fe}_{\mathrm{m}}$. Addition of the refining agents to the hard zinc melt resulted in the formation of different oxides and intermetallic compounds as a slag of refining. Zinc oxide $(\mathrm{ZnO})$ and hematite $\left(\mathrm{Fe}_{2} \mathrm{O}_{3}\right)$ were present in the slag with the all used refining agents. Phase of iron-zinc $\left(\mathrm{Fe}_{3} \mathrm{Zn}_{10}\right)$ was present in the slag due to $\mathrm{Zn}$ addition, while phases of aluminum oxide $\left(\mathrm{Al}_{2} \mathrm{O}_{3}\right)$ and aluminum iron, $\left(\mathrm{FeAl}_{2}\right)$ were formed due to $\mathrm{Al}$ and $\mathrm{Zn} / \mathrm{Al}$ mixture additions. A refined zinc containing $0.5 \mathrm{wt} \% \mathrm{Fe}$ was obtained by adding $0.4 \mathrm{wt} \%$ $\mathrm{Al}$ at $700{ }^{\circ} \mathrm{C}$ after $2 \mathrm{~h}$ of refining. The produced refined zinc is suitable for re-use in the steel galvanization process.

\section{REFERENCES}

[1] S. Dionne, "The characterization of continuous hot-dip galvanized and galvannealed steels", Jouranl of Minerals, Metals and Materials, vol. 58 pp. 32-40, March 2006.

[2] A.F.S.Schoukens, F. Shaw, and E.C. Chemaly, "The Enviroplas process for the treatment of steel-plant dusts", Journal of the South African Institute of Mining and Metallurgy, vol. 93 pp. 1-7, January 1993.

[3] N.A. Barcza, D.G.C. Robertson, A.F.S. Schoukens, F. Shaw, G.M Denton, A.W. Worcester, and D.J. Bailey, "Enviroplas technology for the recovery of lead and zinc from lead blast furnace slag", Recycling lead and zinc into the 21st Century: 6th International Conference of the International Lead and Zinc Study Group', Madrid, Spain, 23-28 June, 1995.

[4] G. Assis, Emerging pyrometallurgical process for zinc and lead recovery from zinc-bearing waste materials, 37th Zinc and Lead Processing Symposium (CIM Meeting), 16-19 Calgary, Canada, August 1998, pp. 243-265.

[5] M.A. Abdel-Latif, , "Fundamentals of zinc recovery from metallurgical wastes in the Enviroplas process", Minerals Engineering, vol. 15 pp. 945-952, September 2002.

[6] G. Glover, "The modeling and simulation of a packed distillation column for use in lead-zinc refining, Part 1: Model Development. Mintek Technical Memorandum No. 14696", 2001.

[7] G. Glover, "The modeling and simulation of a packed distillation column for use in lead-zinc refining", Part 2: Mass Transfer Efficiency. Mintek Technical Memorandum No. 14698, 2001.

[8] A. McKenzie, "A new process for the thermal refining of zinc: A case study of technology development at Mintek", The Journal of the South African Institute of Mining and Metallurgy, vol. 104, pp. 315-322, July 2004.

[9] R.A. Devilee, , A. Van Sandwijk, and M.A. Reuter, , "Selective removal of iron contaminations from zinc-chloride melts by cementation with zinc", Metallurgical and Materials Transactions, vol. 30B, p.607, August 1999.

[10] M. Epstein, K. Ehrensberger, A. Yogev, "Ferro-reduction of $\mathrm{ZnO}$ using concentrated solar energy", Energy, vol. 29, pp. 745-756, April-May 2004.

[11] F. Molnar, and J. Cech, "Possibilities of $\mathrm{Zn}-\mathrm{Al}$ alloy preparation by refining of hard zinc apart iron by aluminum", Acta Metallurgica Slovaca, vol. 11, pp. 74-77, 2005.

[12] F. George, V. Vander Eds., ASM Handbook, Metallography and Microstructures, The Materials Information Society, Materials Park, Ohio 44073-0002. 1995, vol. 9. 